\title{
WISATA EDUFARMING BERBASIS URBAN
}

\author{
Athalia $^{1)}$, Sutarki Sutisna ${ }^{2)}$ \\ ${ }^{1)}$ Program Studi S1 Arsitektur, Fakultas Teknik, Unviersitas Tarumangara, athalialie@hotmail.com \\ 2) Program Studi S1 Arsitektur, Fakultas Teknik, Universitas Tarumanagara, sutarkis@gmail.com
}

\begin{abstract}
Abstrak
Dikenal sebagai negara agraris, Jakarta sebagai ibu kota Indonesia juga memiliki jejak pertaniannya sendiri. Namun dalam menghadapi permasalahan perkotaan dan sosial zaman sekarang, budaya bertani sebagai salah satu ciri khas negara kita terdorong semakin mendesak untuk ditanamkan kembali dalam diri tiap penghuni kota. Terutama kepada generasi muda bangsa. Melalui Wisata Edufarming Berbasis Urban, pengunjung diajak untuk mengenal lebih lanjut sejarah agrowisata negara yang diterapkan dalam bentuk urban sehingga dapat diterapkan di rumah masing-masing kelak. Pengunjung berkesempatan untuk turun langsung ke ladang akuaponik dan hidroponik yang tersedia baik di dalam maupun luar ruangan untuk mempelajari proses pertanian dari awal hingga pemetikan. Tersedia pula pasar untuk memperjual-belikan hasil panen proyek, restoran untuk para pengunjung langsung menyantap hasil petikannya, dan laboratorium serta wadah lokakarya untuk lebih memperdalam teknik pertanian urban. Letak proyek di antara Hutan Kota Srengseng dan Pasar Bunga Rawa Belong berperan sebagai pengisi rantai yang hilang di antara kedua objek melalui fasilitas shuttle bus antar ketiga lokasi. Dalam pelaksanannya, wisata urban agrikultur ini tidak difokuskan untuk nilai ekonominya sebagai sumber pangan, namun juga untuk mewadahi hobi dan komunitas bercocok tanam yang ada di perkotaan. Nilai ekologis yang akan dirasakan oleh masyarakat luas selain menambah penghijauan kota (secara langsung maupun tidak), memperbaiki iklim kota, mendaur ulang limbah organik serta air, mengurangi jejak karbon, dan efek perpanjangan lainnya.
\end{abstract}

Kata kunci: kota, pertanian, wisata

\begin{abstract}
Known as an agricultural country, Jakarta as Indonesia's capital city also has its own agricultural traces. However, facing the existing urban and social problems, the farming culture as one of our country's identity has grown more urgent to be implemented back in each citizens of the city, especially the youth of the country. Through Urban Edufarming Tourism, visitors are invited to get to know the country's agricultural history in the urban form so that they can practice it in their own house later on. Visitors get the chance to experience firsthand the aquaponic and hidroponic fields scattered both indoor and outdoor to learn the farming process from the beginning till the harvesting. Also provided, market where the project's harvest are sold and bought, restaurant where visitors can consume or process how their picks are going to be consumed, and lab with workshops where further research regarding urban farming is conducted.. The project is located between Srengseng City Forest and Rawa Belong Flower Market to fill the mising link between the two objects through a shuttle bus facility between the three locations. The implementation of Urban Farming is not focused in the economic values as a source of food, but also to accomodate farming hobbies and communities in the city. The ecological traits that are experienced by the public besides adding greenery to the city (directly or indirectly), tackling the urban island heat, recycling organic waste and water, reducing the carbon footprint, and other prolongated effects.
\end{abstract}

Keywords: agriculture, tourism, urban

\section{PENDAHULUAN}

Kota Metropolitan diartikan sebagai kota yang memiliki lebih dari satu juta penduduk di dalam batas administrasi kotanya. Umumnya kota merupakan kutub pertumbuhan 
wilayah yang memiliki peran menstimulasi perkembangan kota-kota di sekitarnya dan membangkitkan pertumbuhan ekonomi regional dan nasional. Salah satu definisi metropolis menurut Jean Bastie dan Bernard Dezert (1991) adalah sebagai tempat penting aktivitas-aktivitas budaya dan ilmiah serta sebagai tempat tujuan wisata internasional.

Semakin berkembangnya zaman, terlihat bahwa perkembangan suatu kota tidak lagi dinilai hanya semata-mata dari ekonominya namun juga dari nilai pariwisatanya. Jakarta sebagai ibu kota negara agraris Indonesia pun tidak terlepas dari gelombang pariwisata mancanegara. Salah satu permasalahan yang tengah dihadapi perkotaan zaman sekarang meliputi tergerusnya budaya suatu kota, seperti jejak pertanian Jakarta. Wisata pertanian berbasis kota (urban farming) diharapkan dapat menjawab kebutuhan perkotaan baik dari bidang hiburan maupun budaya.

Selain mempertimbangkan keterbatasan lahan, aktivitas di dalam proyek juga berkesinambungan dengan fasilitas baik pertanian maupun ekologis yang berupa pasar tanaman serta taman publik di Jakarta. Pasar Bunga Rawa Belong sebagai pasar bunga paling aktif di Jakarta merupakan sebuah objek wisata yang terlupakan dengan Hutan Kota Srengseng yang berlokasi tidak jauh darinya. Dengan menghubungkan kedua lokasi dan mempertimbangkan kebutuhan dari masyarakat perkotaan maupun komunitas yang ada, maka dibutuhkan sebuah objek wisata yang mampu mengakomodasi kedua objek potensial di area barat Jakarta tersebut.

\section{METODE}

Metode perancangan yang digunakan adalah kualitatif melalui studi literatur dan media internet mengenai bangunan-bangunan dengan fungsi serupa seperti; Sunqiao Urban Farming District di Shanghai, RRC, Grace Farms di New Canaan, Amerika Serikat, Taman Pertanian Kanak-Kanak di Dong Nai, Vietnam, dan Agrowisata Sistemik di Chili. Proses tersebut dilakukan bertujuan untuk menentukan program, ruang, dan luasan yang diperlukan dalam menciptakan wisata edufarming berbasis urban. Program ruang yang didapatkan juga didukung dari buku Neufert Architects' Data, dan Time-Saver Standard. Selain dari segi arsitektur, juga dilakukan studi literatur untuk teknik-teknik urban farming dari data sekunder, yaitu internet dan buku.

\section{DISKUSI DAN HASIL \\ Dasar Teori}

Sebagai industri yang paling besar dan berkembang dengan cepat di dunia, pariwisata merupakan salah satu faktor terkuat dalam ekonomi dunia. Organisasi-organisasi internasional pun mendukung sektor pariwisata berkat kontribusinya terhadap kedamaian dunia, peringanan kemiskinan, dan peleburan budaya. Menurut United Nation World Tourism Organization pada tahun 2006 sektor pariwisata telah berkembang dalam konteks destinasi wisata yang menyebar dalam ekspansi geografis di seluruh dunia yang memungkinkan negaranegara berkembang untuk menumbuhkan sektor pariwisata mereka dengan kecepatan masing-masing untuk peningkatan ekonomi. Law (1996: 1) mengutarakan bahwa kota merupakan jenis destinasi pariwisata yang paling penting di dunia sejak tahun 1980-an. Sebagai fenomena kepariwisataan dunia, kota dipandang sebagai suatu proses kompleks yang terkait dengan budaya, gaya hidup, dan sekumpulan permintaan yang berbeda terhadap liburan dan perjalanan (Page, 1995: 1). 


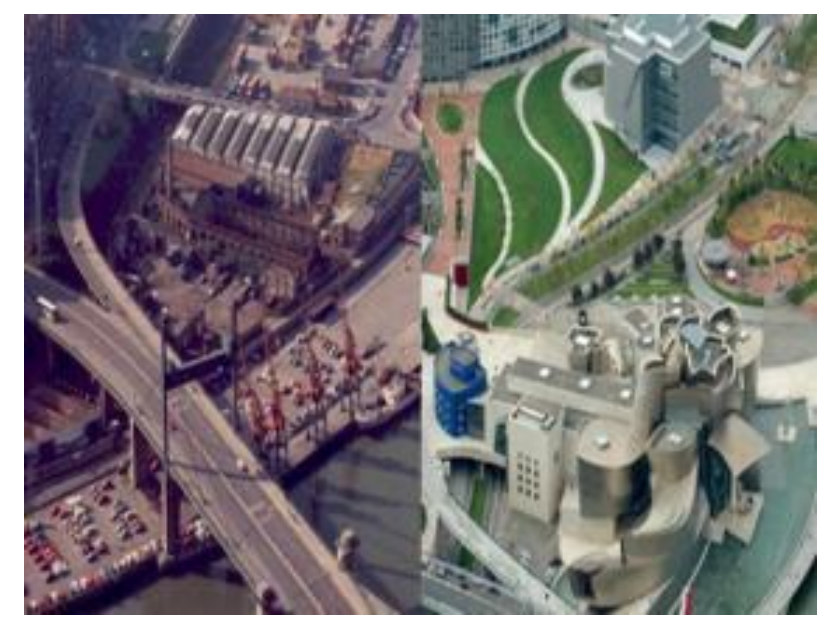

Gambar 1. Sebelum dan Sesudah "The Bilbao Effect"

Sumber: https://www.skyscrapercity.com/showthread.php?p=139954853

"Bilbao Effect" pada tahun 1997 merupakan salah satu momen bersejarah yang membuktikan pentingnya sektor pariwisata bagi sebuah kota. Terjangkit oleh gerakan terorisme separatis Basque, kota industri Bilbao, Spanyol, membutuhkan sebuah "pendorong pembaruan ekonomi" yang kemudian terjawabkan melalui Museum Guggenheim Bilbao karya Frank Gehry. Sang arsitek kelahiran Amerika-Kanada tersebut tidak menyangka bahwa rancangannya akan membawa dampak sebesar itu ketika la menerima proyek yang diharapkan dapat menandingi Sydney Opera House. Bentukan massa museum yang unik, kontemporer, dan kontras, namun tetap melebur dengan lingkungan sekelilingnya berhasil menarik turis dari seluruh penjuru dunia yang kini jumlahnya mencapai jutaan tiap tahunnya. Ekonomi kota yang meningkat drastis dari sektor pariwisata, menimbulkan pertanyaan bagi para ahli ekonomi, sebarapa besar peran arsitektur dalam keberhasilan sebuah objek wisata hingga mempengaruhi kota tempat objek itu sendiri berada?

Museum Guggenhem Bilbao bukan merupakan bangunan pertama yang arsitekturnya berhasil menjadi daya tarik utama sebuah objek wisata. Nama-nama seperti Menara Eiffel dan Piramid Giza tentu tidak asing di telinga kita yang diikuti dengan bentuk arsitekturalnya. Fenomena tersebut terbuktikan karena walaupun seringkali sebuah objek wisata dikaitkan dengan alam, yang notabene sudah terbentuk dari awal oleh Sang Maha Kuasa (lanskap), namun seiring zaman berkembang, dan urbanisasi semakin marak, sebuah kota tidak dapat sekedar hidup tanpa adanya hiburan bagi para pengunjung ataupun penghuninya. Maka dari itu terciptalah objek wisata buatan manusia yang kerap dihubungkan dengan arsitektur.

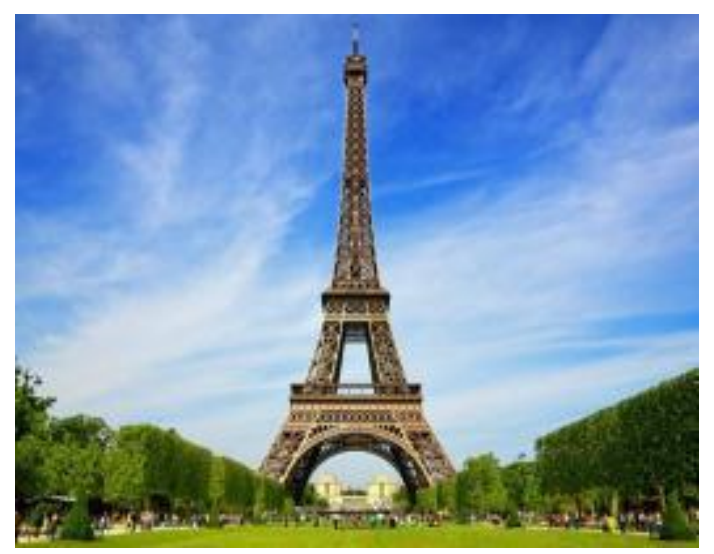

Gambar 2. Menara Eiffel sebagai Lambang Kota Paris

Sumber: https://www.planetware.com/paris/eiffel-tower-f-p-et.htm 


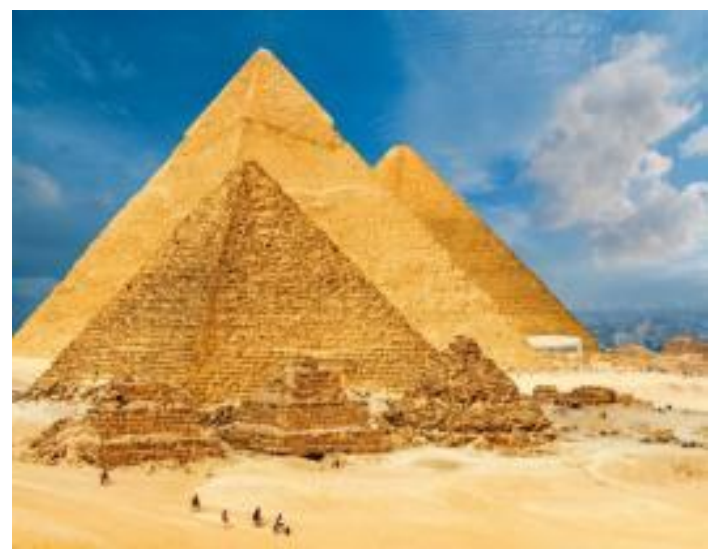

Gambar 3. Piramid di Giza sebagai Lambang Kota Mesir

Sumber: https://www.nationalgeographic.com/archaeology-and-history/archaeology/gizapyramids/

"Hingga bangkitnya turisme massal di pertengahan akhir abad ke-19, sebuah kota dianggap sebagai destinasi perjalanan," ucap Judd (2003). Hal tersebut membuktikan bahwa terdapat hubungan erat sebuah objek wisata dalam kota dengan perkotaan dalam segala aspek. Bila kita merujuk kembali kepada "Bilbao Effect", sebuah karya arsitektur bahkan dapat menjadi wajah bagi kota itu sendiri. Sebagaimana contohnya pada Paris yang sering dikaitkan dengan Menara Eiffel ataupun Piramid Giza dengan Mesir. Berbeda dari contoh-contoh lainnya, Museum Guggenheim Bilbao kembali menjadi tonggak bersejarah bangkitnya arsitektur kontemporer dalam dunia turisme yang kemudian menyebabkan ikon-ikon kota tidak terbatas lagi dengan arsitektur-arsitektur bersejarah atau monumen dari era-era sebelumnya.

\section{Kompleksitas Proyek}

Potensi Pariwisata Jakarta

Sebagai salah satu negara berkembang, perekonomian negara Indonesia juga bergantung dari sektor pariwisata. Bahkan bukan merupakan sebuah pernyataan yang berlebihan bahwa memang sektor pariwisata merupakan primadona baru bagi pembangunan negara kita. Sumnbangan devisa maupun penyerapan tenaga kerja dalam sektor ini amat signifikan bagi devisa negara. Bahkan, diperkirakan pada tahun 2019 sektor pariwisata akan mengalahkan pemasukan devisa dari industri kelapa sawit (CPO) dan menjadi penyumbang utama devisa Indonesia. Negara kita juga dinilai sebagai salah satu dari 20 negara dengan pertumbuhan paling cepat di sektor pariwisata dengan mencapai angka $25,68 \%$ dalam beberapa tahun terakhir.

Jakarta sebagai ibu kota Indonesia sendiri juga merupakan salah satu dari kota-kota yang berhasil menjadi destinasi favorit para turis. Pada tahun 2017 lalu tercatat bahwa Jakarta berhasil memperoleh 2,6 juta kunjungan wisatawan mancanegara, walaupun angka tersebut masih kalah dari Bali. Para ahli menilai Jakarta memiliki segudang potensi untuk mengembangkan sektor pariwisata untuk mendongkrak ekonomi kota. Dalam laporan berjudul Asia Pacific City Travel \& Tourism Impact yang dikeluarkan oleh World Travel and Tourism Council (WTTC), Jakarta ditempatkan sebagai salah satu kota dengan pertumbuhan pariwisata tertinggi di dunia. Diprediksi kelak Jakarta mampu meningkatkan industri pariwisatanya sebesar $10 \%$ dalam sepuluh tahun ke depan. 


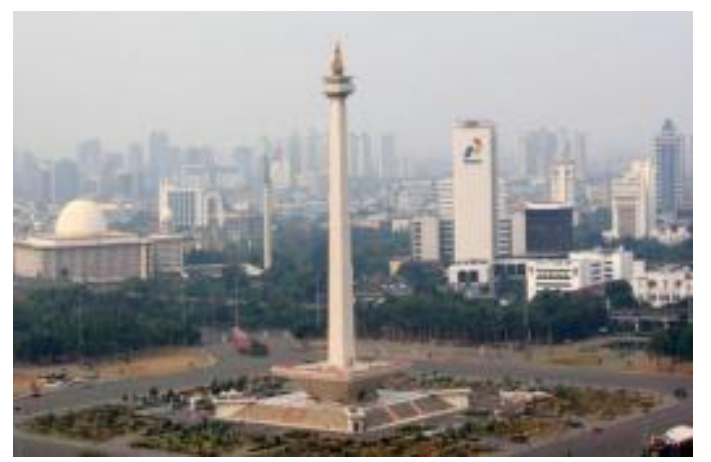

Gambar 4. Monumen Nasional sebagai Lambang Kota Jakarta

Sumber: https://www.merdeka.com/peristiwa/sejarah-dan-kisah-sesosok-wanita-misterius-dipuncak-monas.html

Berikut potensi dan masalah pengembangan pariwisata di DKI Jakarta yang dibentuk oleh Dinas Pariwisata dan Kebudayaan :

1 DKI Jakarta merupakan salah satu pintu gerbang utama wisatawan mancanegara di Indonesia > C Citra pariwisata DKI Jakarta memburuk sejak terjadinya krisis moneter pada pertengahan tahun 1997

2. Sebagai kota multietnis yang unik $>$ Daya tarik objek wisata masih lemah antara lain karena prasarana dan sarana yang tersedia belum memadai, terjadinya perubahan penggunaan ruang, kebersihan dan keindahan kurang terpelihara

3. Memiliki fasilitas lingkungan perkotaan yang mendukung terbentuknya "Service City" $><$ Apresiasi dan pemahaman masyarakat terhadap pembangunan pariwisata belulm merata dan masih terbatas

4. Memiliki sejumlah objek wisata baik yang bernuansa alam berbasis minat maupun bernuansa bisnis $><$ Koordinasi antar sektor yang terkait masih lemah

5. Memiliki sejumlah objek wisata baik yang bernuansa alam berbasis minat maupun bernuansa bisnis > Publikasi dan info objek wisata beserta atraksinya masih sangat terbatas dan kurang komunikatif

6. Memiliki sejumlah objek wisata baik yang bernuansa alam berbasis minat maupun bernuansa bisnis $><$ Kurangnya Sumber Daya Manusia (SDM)

Sumber : Data Potensi Dan Masalah Pengembangan Pariwisata Di Provinsi DKI Jakarta - Dinas Pariwisata dan Kebudayaan

\section{Wisata Ekologi di Jakarta}

Populasi 7.3 milyar jiwa di dunia saat ini terdiri dari setengah penduduknya (54\%) tinggal di area perkotaan yang diperkirakan pada tahun 2050, 66\% dari 9 milyar jiwa kelak akan mengalami urbanisasi (United Nations, 2016). Peningkatan urbanisasi menekan perkotaan untuk memenuhi kebutuhan penghuninya seperti meningkatnya jumlah penghuni dengan ekonomi rendah yang berbanding terbalik dengan ketersediaan lahan, tingginya jejak ekologis, ataupun bencana-bencana dari alam dan akibat manusia sendiri. Pengembangan kota berkelanjutan merupakan kunci penting untuk mendapatkan perkembangan ekonomi dalam sebuah langakah yang berkelanjutan secara lingkungan dan juga untuk menjawab kebutuhan mendasar dari penghuni kota.

Sementara wisata kota dapat membantu meningkatkan vitalitas ekonomi perkotaan, pengembangan budaya wisata dan wisata berbasis ekologi dapat membantu meningkatkan keunuikan suatu kota. Wisata berkelanjutan dapat membantu menjaga lingkungan dan integritas budaya komunitas-komunitas, melestarikan budaya peninggalan, dan melindungi area-area yang sensitif secara ekologi. 
Tercatat bahwa sektor pertanian menyerap 35.9\% dari total angkatan kerja di Indonesia dan menyumbang $\mathbf{1 4 . 7 \%}$ bagi GNP Indonesia (BPS, 2012). Sebagai ibu kota negara agraris dengan kelimpahan sumber daya alam yang tercatat merupakan terbesar nomor dua di dunia setelah Brazil dalam biodiversitas daratnya dan nomor satu di dunia dari segi biodiversitas lautnya , Jakarta juga memiliki "legenda" agrikulturnya sendiri. Jejak "legenda" tersebut dapat ditelusuri dari nama-nama daerah di Jakarta yang menggunakan kosa flora atau fauna seperti Cempaka Putih, Pondok Labu, Kampung Rambutan, Salak Condet, Gandaria, dan sebagainya.

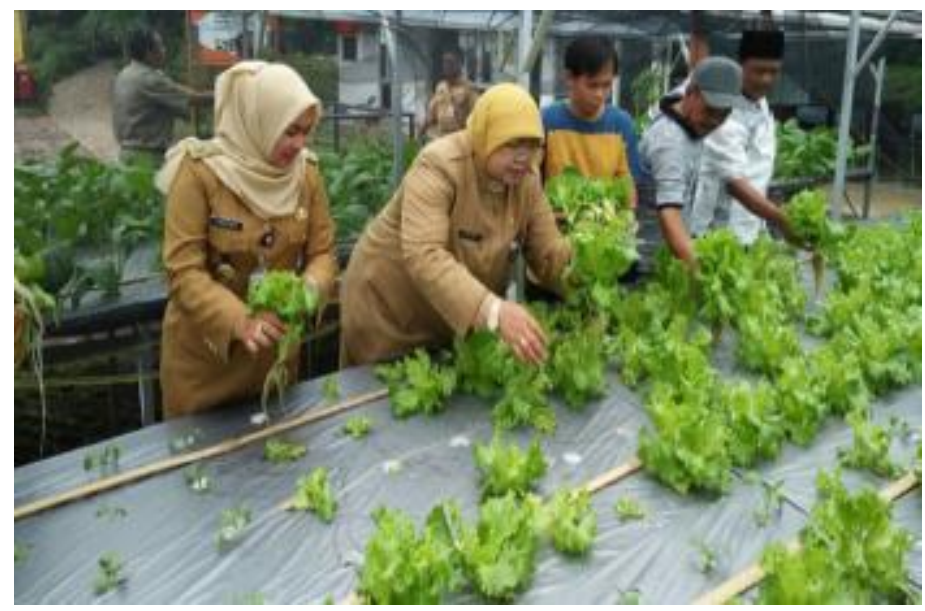

Gambar 5. Pemerintah Mendorong Kegiatan Urban Farming di Jakarta Sumber: https://www.indopos.co.id/read/2018/01/31/125696/urban-farming-marak-jakartalebih-hijau

Urban Agrikultur memegang kunci penting untuk mendukung ketahanan pangan dan kemiskinan. Hal tersebut dapat membantu pengembangan ekonomi lokal dan meningkatkan pengelolaan lingkungan kota. Juga mengambil andil dalam mengurangi iklim kota, penyimpanan air, pengelolaan limbah, dan penghijauan kota. "Urban Agrikultur adalah sebuah komplementer terhadap agrikultur rural, namun merupakan sebuah keharusan untuk pangan dan pengetahuan agrikultur" ujar Dr. Joe Nasr dalam International Research on Food Insecurity, Natural Resource Management, and Rural Development. Menurutnya urban agrikultur akan tetap menjadi pemasok pangan tambahan dengan fungsi utamanya sebagai pendukung biodiversitas spesies, alih-alih sebagai sumber pangan utama.

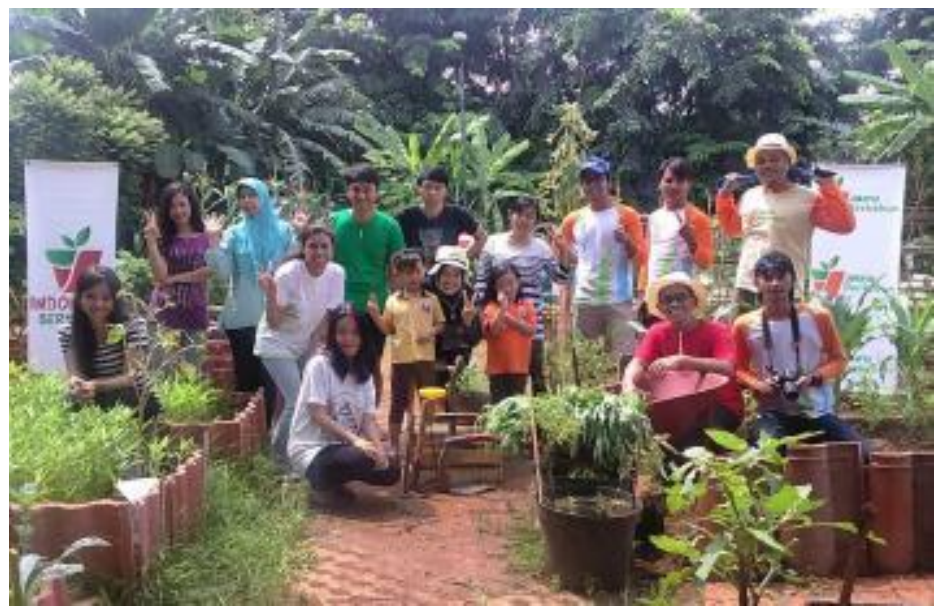

Gambar 6. Komunitas Indonesia Berkebun

Sumber: https://komunita.id/2016/02/04/indonesia-berkebun-sosialisasikan-cara-bercocoktanam-di-kawasan-perkotaan/ 
Dalam penerapannya, Council on Agriculture Science and Technology (CAST) mendefinisikan urban farming mencakup aspek kesehatan lingkungan, remediasi, dan rekreasi. Walaupun dengan lahan terbatas, tidak sedikit penghuni kota yang menekuni urban agrikultur sebagai hobi dilihat dari banyaknya anggota Komunitas Pecinta Tanaman Buah dalam Pot Indonesia (TABULAMPOT Indonesia) dan Komunitas Pecinta Tanaman Hias. Sebagai bagian yang mewarnai Kota Jakarta, komunitas-komunitas lokal akan semakin berkembang dengan didukung fasilitas dan sarana yang tepat baik itu untuk berkumpul, mengadakan pameran, ataupun lokakarya.

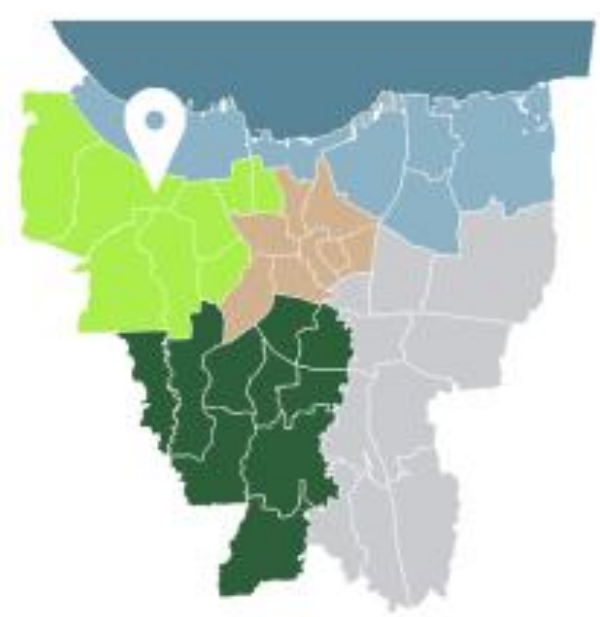

\section{Gambar 7. Posisi Tapak di Dalam Kota}

Sumber: Olahan penulis, 2018

\section{Korelasi dengan Kawasan}

Sebuah objek wisata tidak dapat berdiri sendiri dan harus memiliki korelasi dengan kawasan ataupun objek-objek di sekitarnya. Pemilihan lokasi tapak pun harus dengan mempertimbangkan jaraknya dengan objek-objek wisata lainnya, karena ditemukan hal tersebut merupakan salah satu faktor yang mempengaruhi keberhasilan suatu objek wisata di Jakarta. Dalam kasus ini, proyek harus mampu merajut sebuah hubungan antara fasilitasfasilitas pertanian maupun penghijauan yang sudah ada di kota guna melebur ke dalam perkotaan.

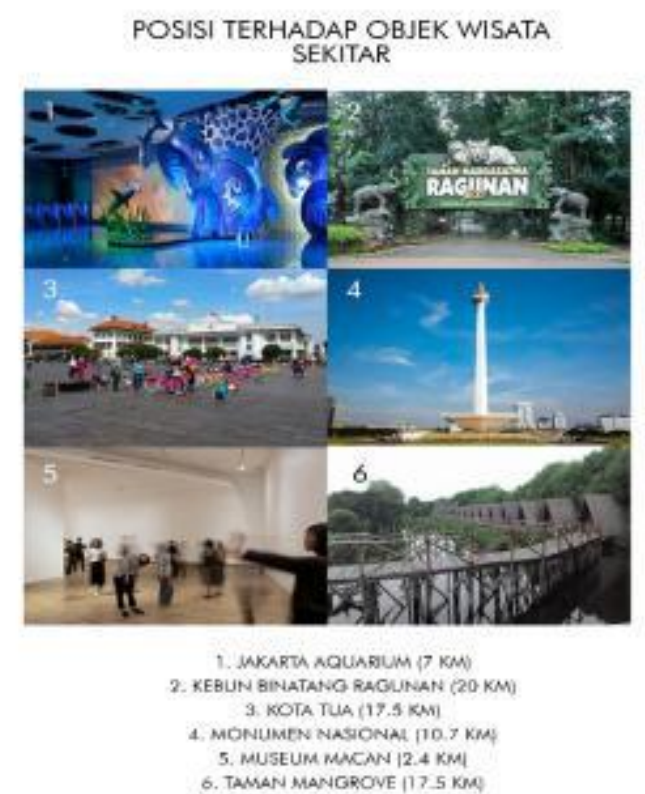

Gambar 8. Kolase Obyek Wisata Sekitar Tapak

Sumber: Olahan penulis, 2018 
Melihat tidak meratanya persebaran objek wisata di bagian-bagian utama Kota Jakarta, tersisa Jakarta Barat yang belum memiliki sebuah objek wisata sebagai landmark kawasan tersebut. Tapak berada dalam jangkauan Bandara Internasional Soekarno Hatta (gateway para turis asing), Kawasan Wisata Kota Tua, Monumen Nasional (ikon Kota Jakarta), serta pesisir utara Jakarta dalam radius $15 \mathrm{~km}$.
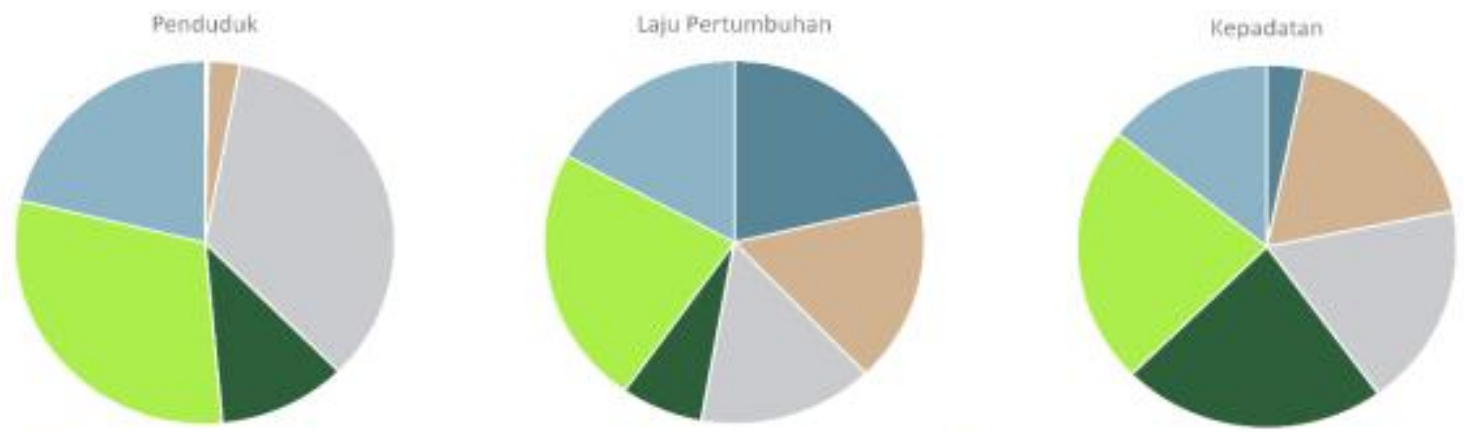

- Kepulauan Seribu " Jakarta Selatan = Jakarta Timur = Jakarta Pusat " Jakarta Barat " Jakarta Utara

Gambar 9. Jumlah Penduduk, Laju Pertumbuhan, Kepadatan Jakarta Tahun 2017 Sumber: Proyeksi Penduduk Sensus Penduduk 2010 Jakarta dalam Angka, 2017

Walaupun daerah selatan dan timur Jakarta terkenal akan kawasan hijaunya di daerah pinggir Jakarta, namun proyek juga ditujukan untuk membantu mengatasi salah satu permasalahan perkotaan. Dari jumlah penduduk, laju pertumbuhan, dan kepadatan, Jakarta Barat memiliki rata-rata terbesar di antara bagian-bagian Jakarta lainnya.

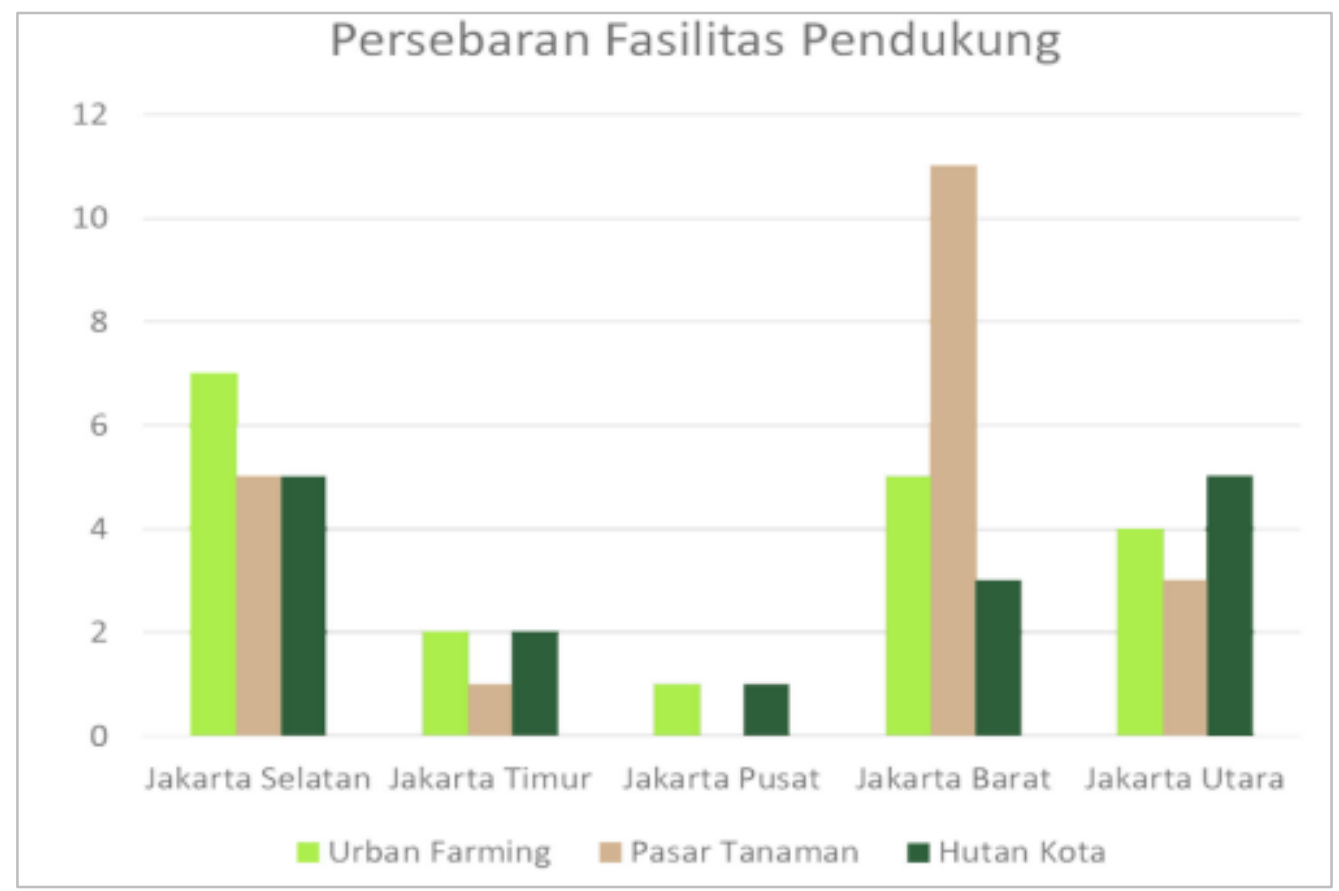

Gambar 10. Persebaran Fasilitas Pendukung

Sumber: Olahan Penulis, 2018

Urban agrikultur tentunya tidak dapat berdiri sendiri tanpa adanya komunitas dan bangunan-bangunan pendukung sekitarnya. Dilihat dari jumlah toko tanaman yang cenderung terpusat di daerah Jakarta Barat dan persebaran komunitas urban farming yang sebagian terdapat di daerah barat juga, maka mendukung pemilihan tapak di area Jakarta Barat. 


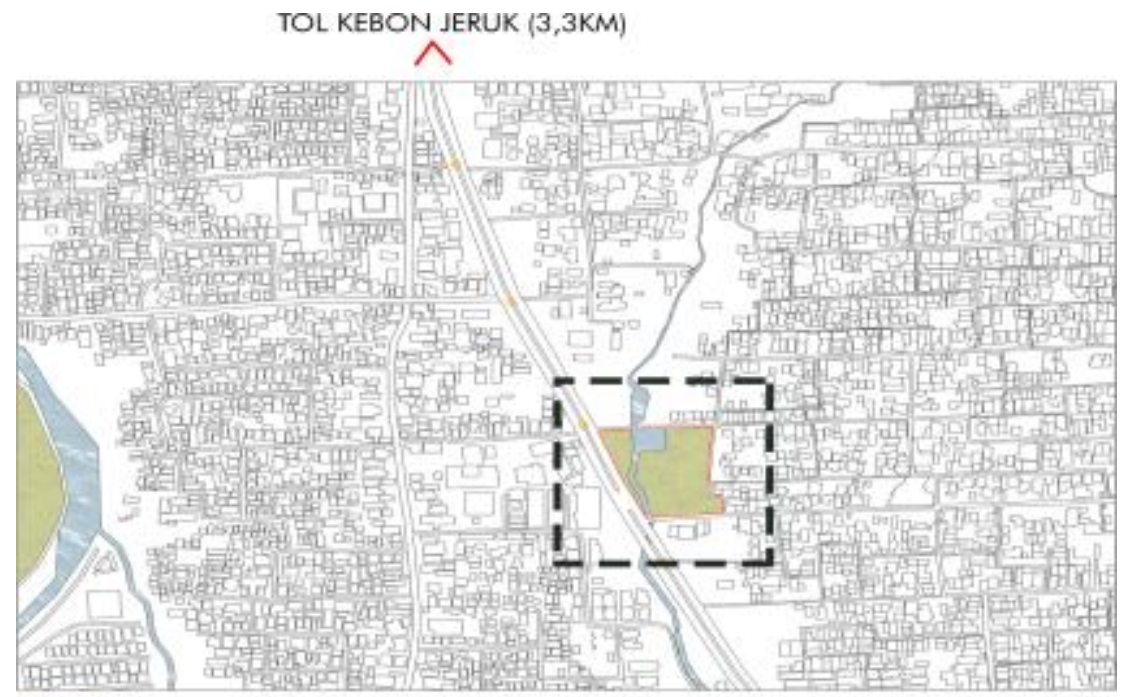

HALTE BUSWAY

Gambar 11. Peta Kawasan Tapak

Sumber: Olahan Penulis, 2018

Tabel 1. Informasi Perbandingan Hutan Kota Srengseng dan Pasar Bunga Rawa Belong

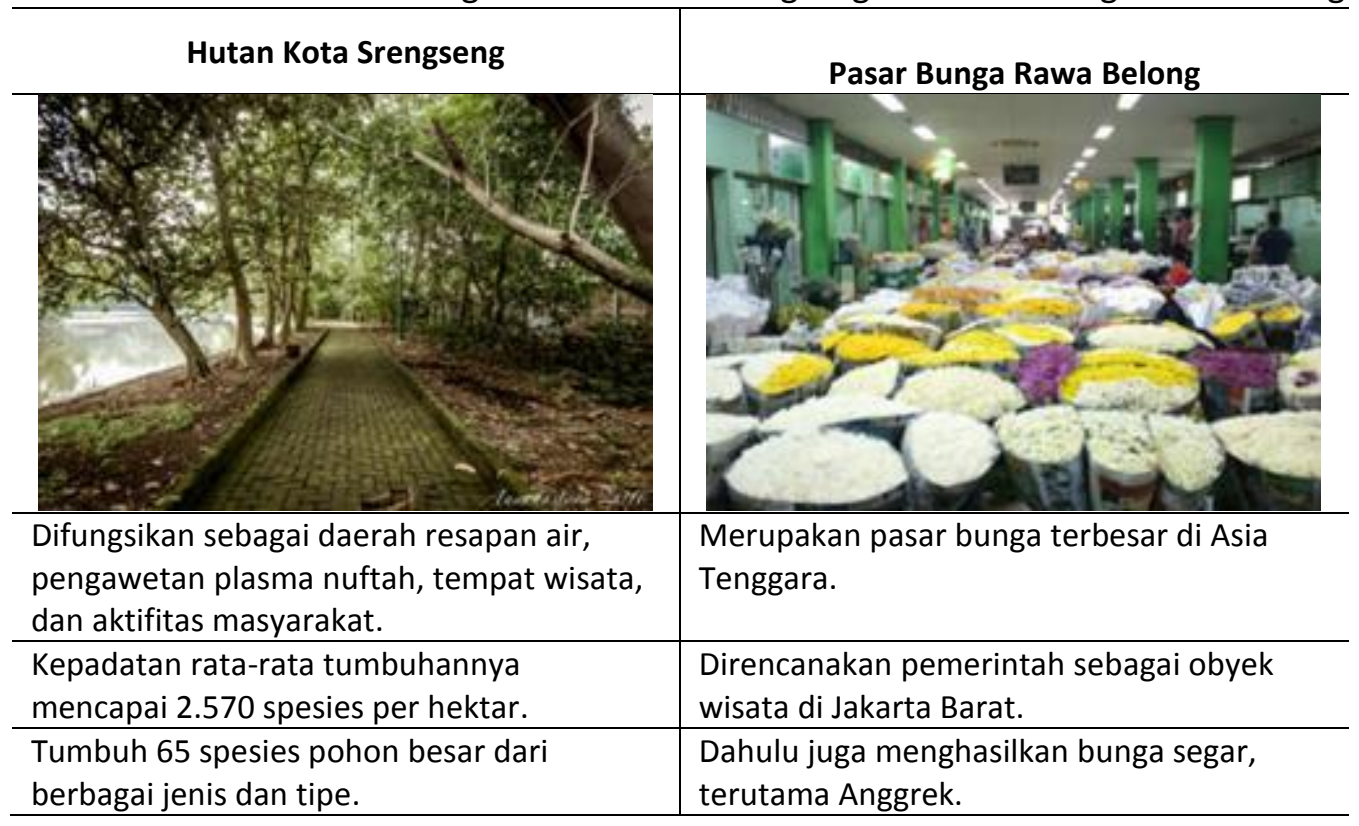

Sumber: Olahan Penulis, 2018 


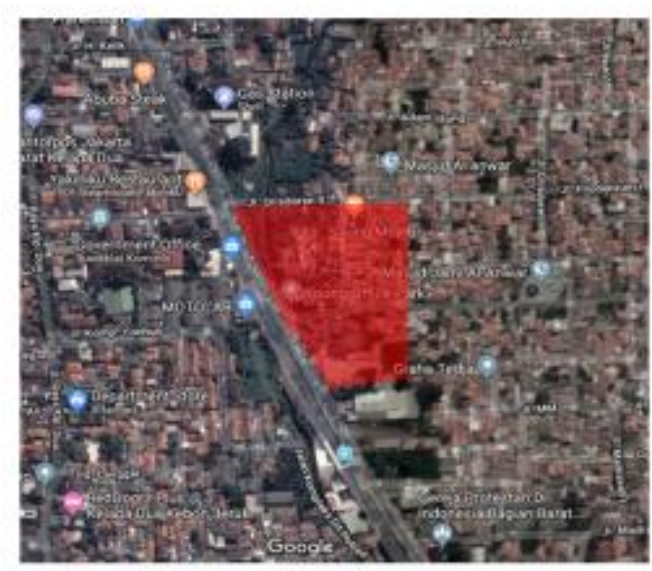

ALAMAT :

JL. ARTERI KELAPA DUA B2, RT.6/RW.5, SUKABUMI UTARA, JAKARTA BARAT, 11540

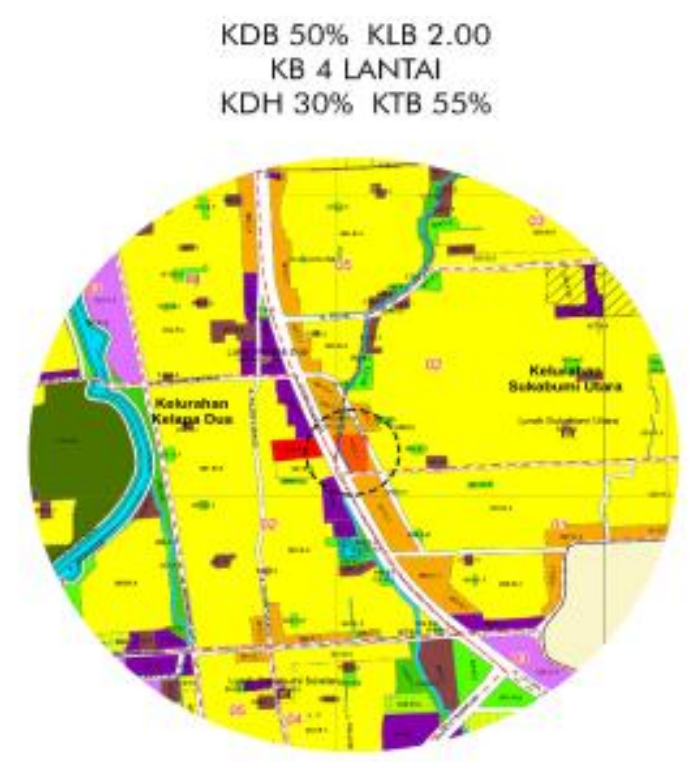

VIEW TAPAK

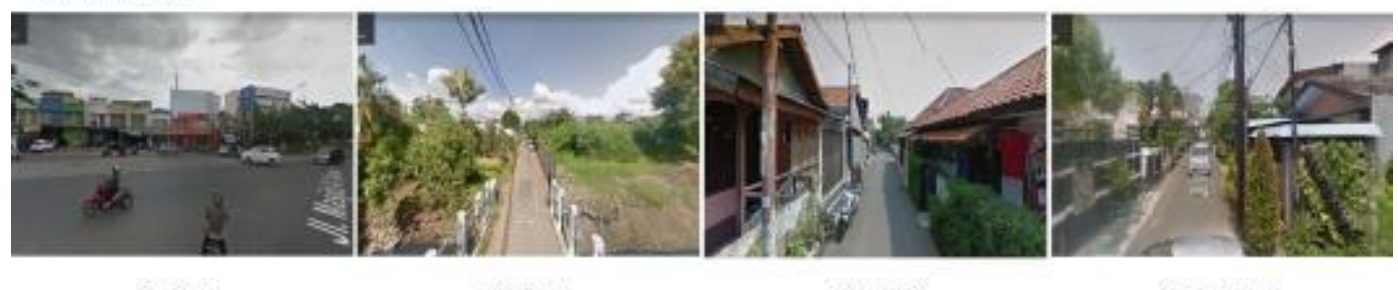

BARAT

UTARA

TIMUR

SELATAN

\section{ANALISA TAPAK}
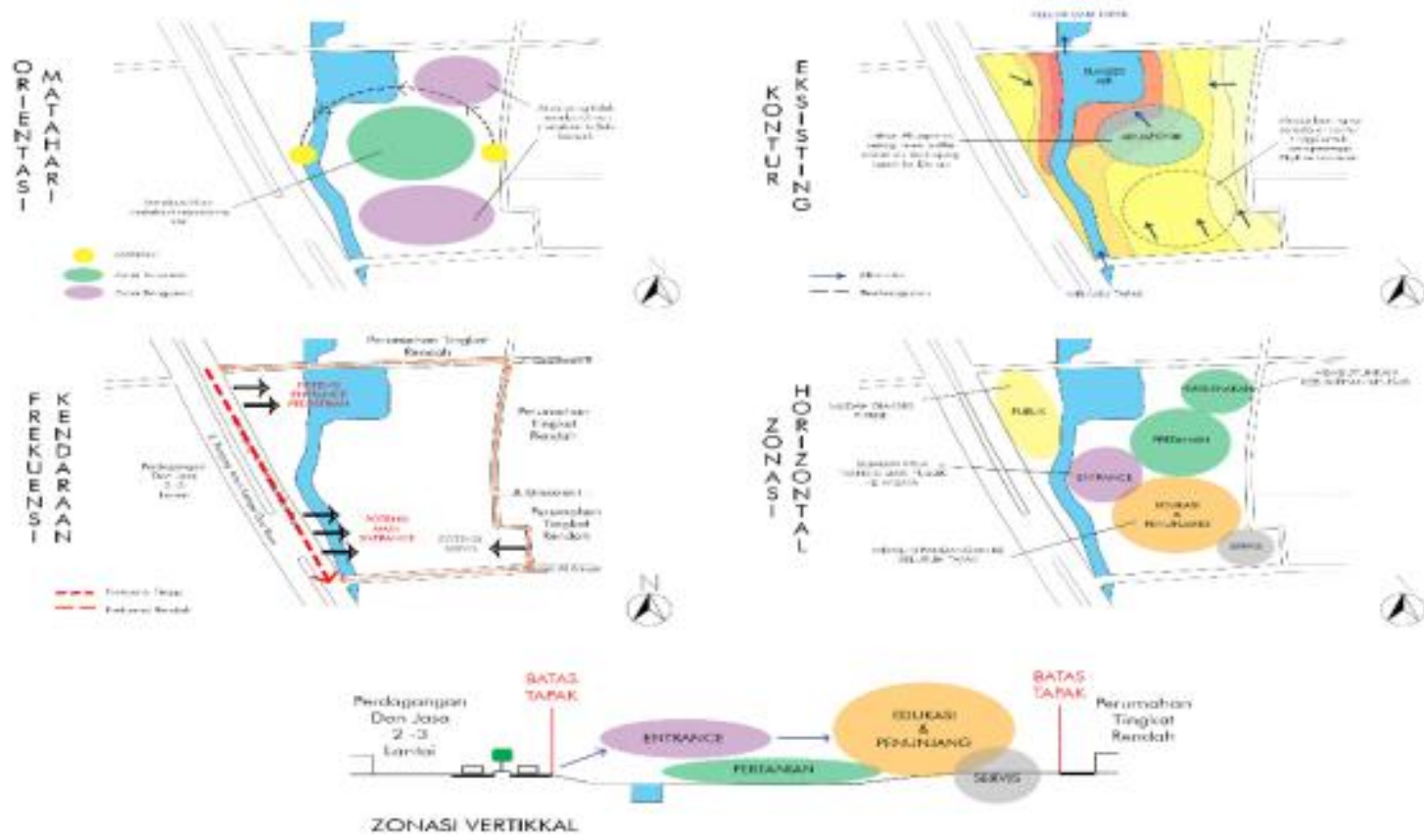

Gambar 12. Analisa Tapak

Sumber: Olahan Penulis, 2018 

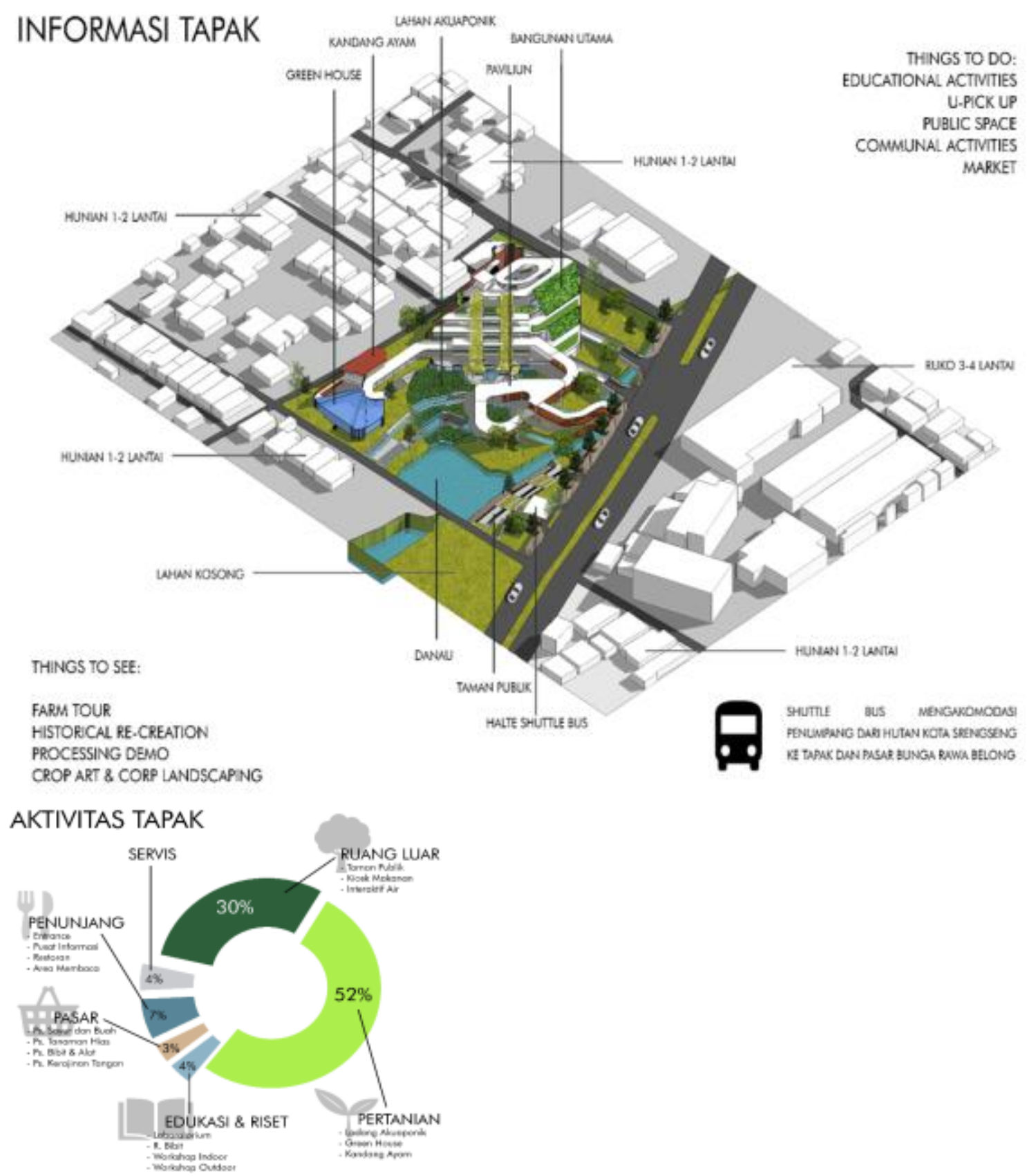

Gambar 13. Konsep dan Pemrograman

Sumber: Olahan Penulis, 2018 
Gambar 14. Gambar Perancangan

Sumber: Olahan Penulis, 2018

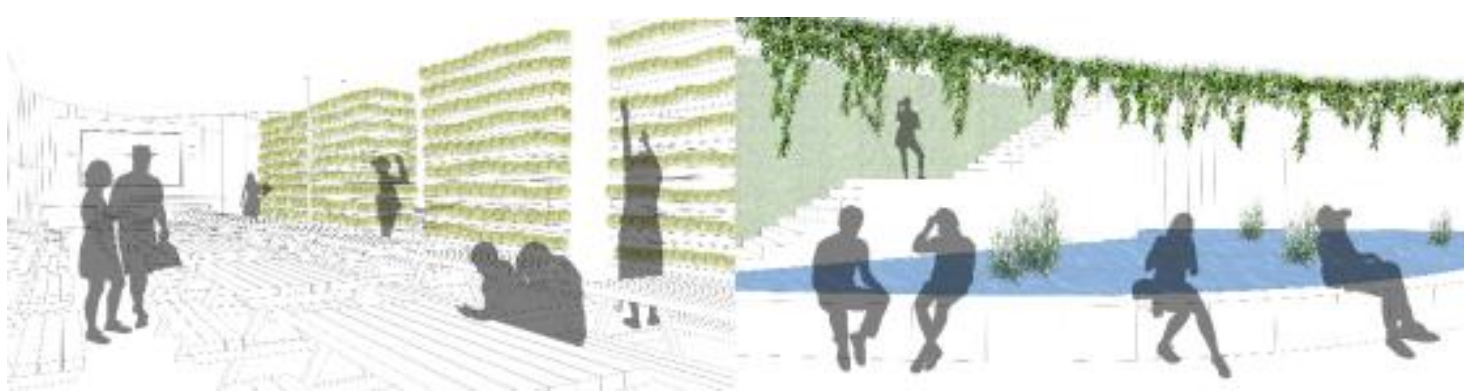

Gambar 15. Gambar Perspektif Interior

Sumber: Olahan Penulis, 2018

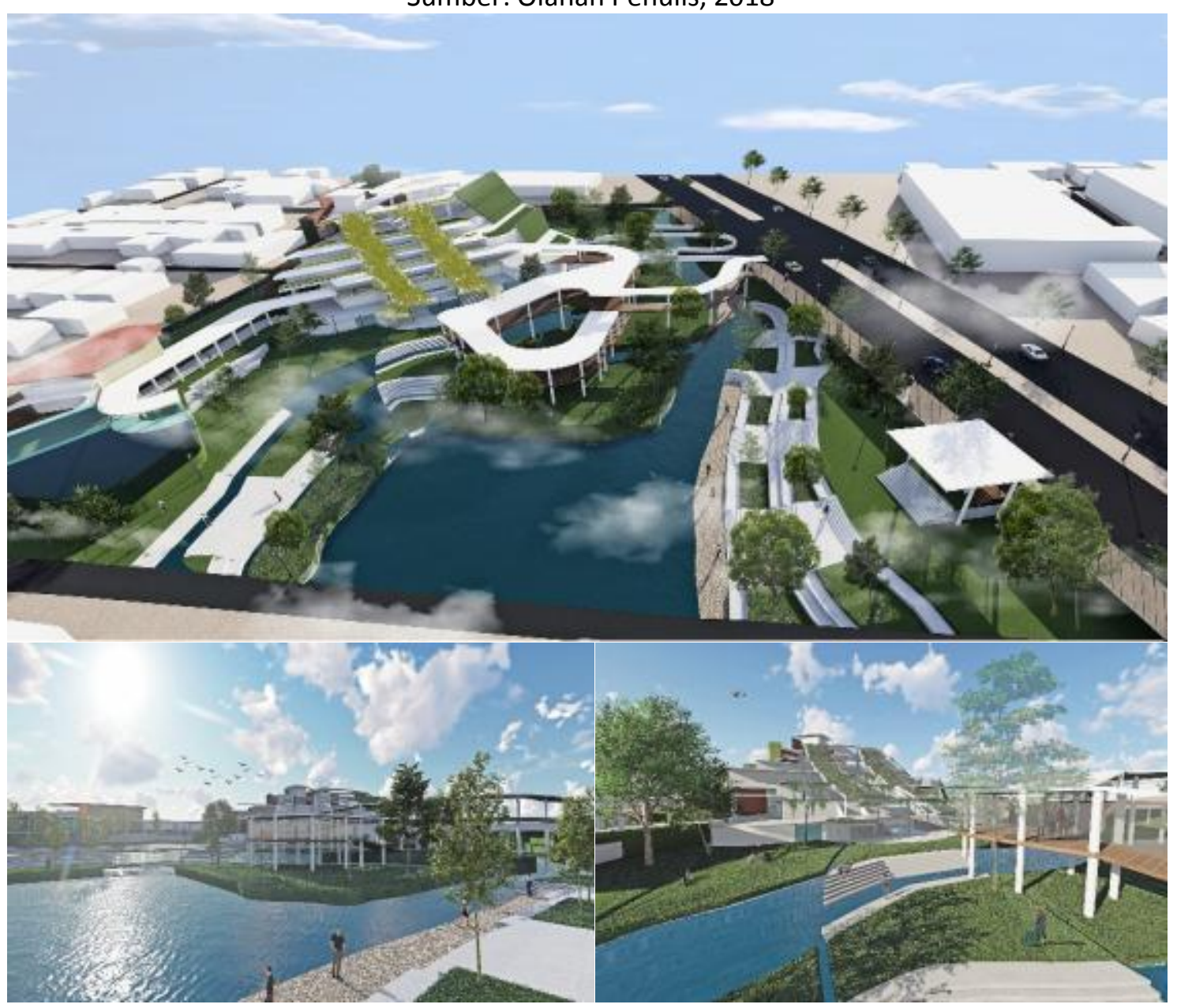

Gambar 16. Gambar Perspektif Eksterior

Sumber: Olahan Penulis, 2018 


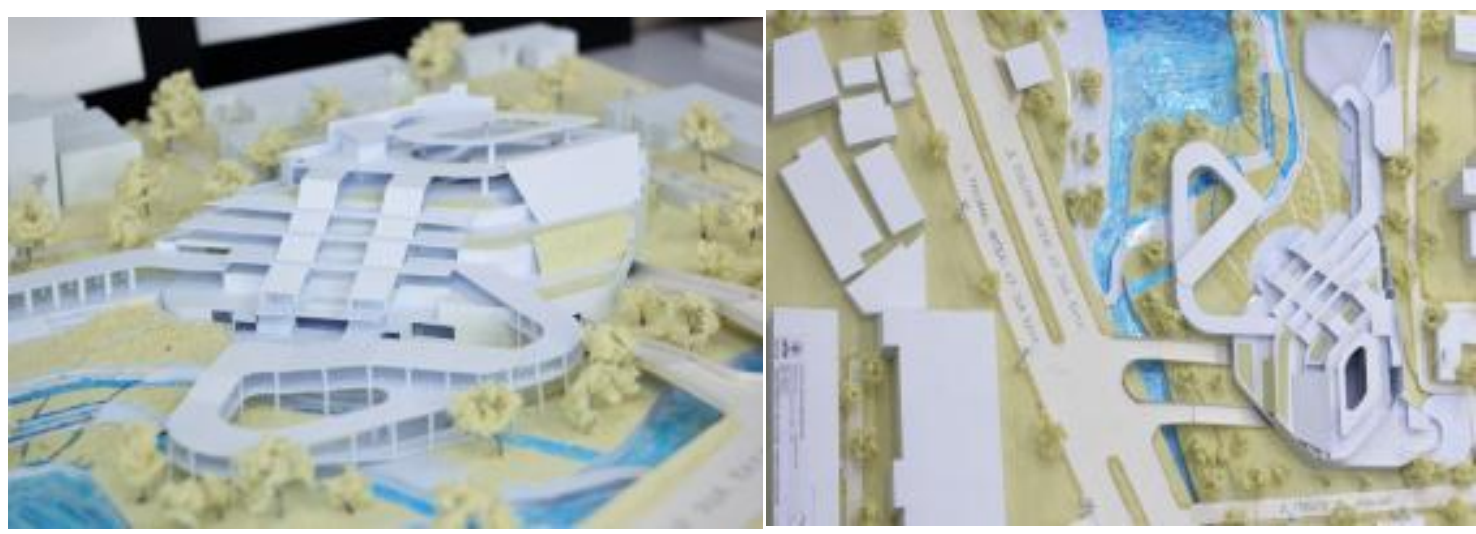

Gambar 17. Foto Maket

Sumber: Dokumentasi Penulis, 2018

\section{KESIMPULAN DAN SARAN}

Wisata Edufarming Berbasis Urban merupakan salah satu bentuk implementasi nilai ekologi ke dalam sebuah objek wisata. Dengan difokuskan terhadap sistem pertanian urban, diharapkan pengunjung dapat menerapkannya kembali di rumah mereka masing-masing serta dapat mengubah gaya hidup masyarakat kota ke arah yang lebih sehat. Selain sebagai penambah penghijauan kota, komunitas-komunitas yang berhubungan dengan urban farming juga terwadahi melalui keberadaan proyek. Hubungan-hubungan yang hilang antar objek wisata, dalam kasus ini, Hutan Kota Srengseng, dan Pasar Bunga Rawa Belong akan terhubungkan dan dihidupkan kembali.

\section{UCAPAN TERIMA KASIH}

Penulis mengucapkan terima kasih kepada Tuhan Yang Maha Esa, orang tua, kakak perempuan, teman-teman, dosen-dosen pembimbing, narasumber, dan pihak-pihak lainnya yang tidak dapat disebutkan satu per satu yang sudah terlibat dalam pembuatan artikel jurnal ini.

\section{REFERERENSI}

Specht, Jan. (2014). Architectural Tourism : Building for Urban Travel Destinations. Wiesbaden: Springer Gabler. ISBN 978-3-658-06023-7

Eruotor, Victor. (2014). "The Economic Importance of Tourism In Developing Countries". Jurusan Pariwisata. Centria University of Applied Sciences. Kokkola

Page, Stephen, (1995). Urban Tourism, Routledge, London.

Biro Perencanaan dan Keuangan Sekretariat Kementrian. 2017. Laporan Akuntabilitas Kinerja Kementrian Pariwisata Tahun 2016.

http://www.kemenpar.go.id/userfiles/LAPORAN\%20KINERJA\%20KEMENPAR\%202016_FIN AL.pdf. 16 Juli 2018

https://www.ruaf.org/urban-agriculture-what-and-why https://rawabelong.wordpress.com/upt-pasar-rawa-belong/ https://www.theguardian.com/artanddesign/2017/oct/01/bilbao-effect-frank-gehry-

guggenheim-global-craze

https://www.azocleantech.com/news.aspx?newsID=17178

https://www.economist.com/special-report/2014/01/06/the-bilbao-effect

https://finance.detik.com/berita-ekonomi-bisnis/d-3687715/tiga-tahun-jokowi-jk-pariwisata-

sumbang-devisa-terbesar-kedua

https://travel.kompas.com/read/2016/10/27/084100327/kembangkan.pariwisata.ini.hambat

an.dan.tantangan.kemenpar.

https://www.liputan6.com/bisnis/read/3141187/pertumbuhan-pariwisata-jakarta-salah-satu- 
yang-tertinggi-di-dunia

http://webcache.googleusercontent.com/search?q=cache:http://gempitanews.com/detailpos t/potensi-sektor-pertanian-di-indonesia

https://megapolitan.kompas.com/read/2017/09/29/19234721/masih-ada-sawah-di-jakartapekan-depan-panen

https://www.kompasiana.com/darwonogurukita/5a676832caf7db4cd8077ab2/urbanfarming-as-edufarming-di-jakarta

http://blog.tropentag.de/node/315

http://www.thejakartapost.com/news/2017/05/23/jakartans-to-see-more-urban-

farming.html

http://jakarta.litbang.pertanian.go.id/ind/index.php/publikasi/artikel/639-konsep-urban-

farming-sebagai-solusi-kota-hijau

https://www.archdaily.com/868129/sasaki-unveils-design-for-sunqiao-a-100-hectare-urbanfarming-district-in-shanghai

https://www.archdaily.com/874922/ilimelgo-reimagines-future-of-urban-agriculture-inromainville

https://www.archdaily.com/566580/farming-kindergarten-vo-trong-nghia-architects https://www.archdaily.com/76055/systemic-agro-tourism-carlos-bartesaghi-koc 